\title{
Large Neutral Amino Acids Transporter Small Subunit 2
}

National Cancer Institute

\section{Source}

National Cancer Institute. Large Neutral Amino Acids Transporter Small Subunit 2. NCI

Thesaurus. Code C119003.

Large neutral amino acids transporter small subunit 2 (535 aa, $58 \mathrm{kDa}$ ) is encoded by the human SLC7A8 gene. This protein plays a role in amino acid transport. 